\title{
Balancing the modern marine barium isotope budget with estuarine processes
}

LUKE BRIDGESTOCK ${ }^{1,2}$, JOSEPH NATHAN ${ }^{2}$, ROB PAVER $^{2}$, YU-TE ALAN HSIEH ${ }^{2}$, DON PORCELLI' ${ }^{2}$, JANI T.I. TANZIL ${ }^{3}$, PHIL HOLDSHIP ${ }^{2}$, GONZALO CARRASCO ${ }^{3}$, KOGILA VANI ANNAMMALA ${ }^{4}$, PETER SWARZENSKI ${ }^{5}$, PER ANDERSSON ${ }^{6}$ AND GIDEON M HENDERSON ${ }^{2}$

${ }^{1}$ Department of Earth Sciences, University of Cambridge

${ }^{2}$ University of Oxford

${ }^{3}$ National University of Singapore

${ }^{4}$ Universiti Teknologi Malaysia

${ }^{5}$ International Atomic Energy Agency

${ }^{6}$ Swedish Museum of Natural History

Presenting Author: 1jb212@cam.ac.uk

Barium isotope variations (expressed as $\delta^{138 / 134} \mathrm{Ba}$ values) recorded by barite and carbonates are a promising new proxy for reconstructing past changes in the marine carbon cycle. A prerequisite to interpreting such records is a full understanding of the modern marine $\mathrm{Ba}$ isotope budget. Currently available data however suggests the $\delta^{138 / 134} \mathrm{Ba}$ of the major marine input (rivers) and output (barite burial) are not in balance. Here we show that this apparent imbalance is likely resolved by accounting for the impact of estuarine processes, which modify both the flux and $\delta^{138 / 134} \mathrm{Ba}$ of dissolved riverine $\mathrm{Ba}$ inputs to the ocean. Using a compilation of literature data, we estimate that rivers supply a net input of $\sim 10$ to $16 \mathrm{Gmol} / \mathrm{yr}$ of $\mathrm{Ba}$ to the ocean, with at least half of this flux being supplied by Ba release from exchangeable sites on riverine sediments during estuarine mixing. New Ba isotope data spanning the estuarine mixing zones of the Amazon, Lena, Yenisey, Ob, Fly and Johor rivers are used to document the impact of this process on the $\delta^{138 / 134} \mathrm{Ba}$ of net riverine inputs. The $\delta^{138 / 134} \mathrm{Ba}$ of the dissolved loads of these rivers are offset to higher values relative to both the upper continental crust and marine barite, consistent with previous data. Cation exchange during estuarine mixing results in the release of $\mathrm{Ba}$ featuring lower $\delta^{138 / 134} \mathrm{Ba}$ than the corresponding dissolved loads. Accounting for this process, the $\delta^{138 / 134} \mathrm{Ba}$ of net marine $\mathrm{Ba}$ inputs from the Amazon, Fly and Johor rivers balance that of marine barite, the main oceanic Ba sink. In contrast the isotope composition of net dissolved $\mathrm{Ba}$ inputs to the ocean from the rivers Lena, Yenisey and $\mathrm{Ob}$ remains offset to higher $\delta^{138 / 134} \mathrm{Ba}$ than both the upper continental crust and marine barite. Overall these results highlight the key role of estuarine $\mathrm{Ba}$ release for controlling the $\delta^{138 / 134} \mathrm{Ba}$ of marine $\mathrm{Ba}$ inputs. Accounting for this process helps to resolve the apparent imbalance in the modern marine $\mathrm{Ba}$ isotope budget, although lithological variability and/or critical zone processes may impart additional variability in the $\delta^{138 / 134} \mathrm{Ba}$ of net river inputs and this warrants further investigation. 